\title{
血液透析患者の自己決定尺度の開発
}

一第 2 回日本透析医学会コメディカルスタッフ研究助成報告一

\author{
岡美智代 安 酸 史子* 保科 良子** 戸 村 成 男*** \\ 土 屋 滋*** \\ 筑波大学大学院博士課程医学研究科 岡山県立大学保健福祉学部看護学科* \\ 横浜第一病院** 筑波大学社会医学系***
}

key words：血液透析患者 (hemodialysis patients), 尺度開発 (scale development), 透析患者の自己決定尺度 (The Self-Determination Scale for Hemodialysis Patients), 自己決定 (self-determination), 信頼性 と妥当性 (reliability and validity)

〈要旨〉

目的：血液透析患者の自己決定尺度 (Self-Determination Scale for Hemodialysis Patients : SSHP) の開発のた めの研究を行った，対象と方法：開発は三つのステップを通して行った，第一ステップはアイテム・プールとカテ ゴリー化である．患者への半構成的インタビューを元に，自己決定のカテゴリー化と質問項目作成，ならびに研究 者らによる質問項目の妥当性の検討を行った。 第ニステップはアイテム・セレクトで, 73 名の血液透析患者への調 査を行った。また，基準関連妥当性検討のため, The Health Self-Determinism Index (HSDI) との関連性の測定を 行った. 第三ステップはアイテム決定で, 201 名の血液透析患者に調査を行った. 結果 : 第一ステップでは, 身体的 不調改善のための自己決定, 医療知識・情報保有による自己決定, 患者一医療者関係に起因する自己決定の 3 カテ ゴリーからなる 18 項目の質問を作成した。第ニステップは, item-total 相関, 因子分析により，身体的不調改善と 知識・情報保有を統合したセルフケアに関する自己決定因子と, 患者一医療者に起因する自己決定因子の 2 因子構 造，15 項目の質問にした。 HSDI との関連性は， $r=0.67$ ( $p<0.001)$ であり，SSHP の基準関連妥当性が認めら れた. 第三ステップでも, item-total 相関, 因子分析を行った. その結果, 第二ステップと同様の 2 因子構造, 14 項 目の尺度となった. Cronbach's $\alpha$ は, SSHP 全体で $\alpha=0.84$, 下位尺度ではセルフケアに関する自己決定の因子が $\alpha=0.83$, 医療者不信に起因する自己決定の因子が $\alpha=0.78$ であり，信頼性が保たれていることが確認された．結 論：2 因子構造, 14 項目の SSHP を作成し, 妥当性と信頼性が確かめられた。

\section{Development of a self-determination scale for hemodialysis patients}

Michiyo Oka, Fumiko Yasukata*, Ryouko Hoshina**, Shigeo Tomura***, Shigeru Tsuchiya*** Graduate School of Medicine, University of Tsukuba ; Department of Nursing, Faculty of Health and Welfare Science, Okayama Prefectural University*; Yokohama Daiichi Hospital**; Institute of Community Medicine, University of Tsukuba***

Objective : Research for development of a Self-Determination Scale for Hemodialysis Patients (SSHP) was conducted. Subjects and Methods: The scale was developed by the following three steps. The first step was item pooling, creating question items on the basis of categorization of self-determination according to moderately structured interviews with hemodialysis patients and reviewing the validity of the question items by the researchers. The second step was item selection for which 73 hemodialysis patients were investigated. In order to confirm the criterion-related validity of SSHP, its relationship with the Health Self-Determinism Index (HSDI) was examined. The third step was item decision for which 201 hemodialysis patients were investigated. Results: At the first step, 18 question items, which consisted of 3 categories of self-determination, were obtained. At the second step, 15 question items, which consisted of 2 self-determination factors : , i.e., self-care and patient-medical staff relationship, were selected by item-total correlation and factor analysis. The criterion -related validity of SSHP was confirmed because its relationship with HSDI was significant $(r=0.67, p<$

岡 美智代 筑波大学大学院博士課程医学研究科厂３05 つくば市天王台 1-1-1 (0298-53-3210) 
0.001). At the third step, item-total correlation and factor analysis were also conducted, and 14 question items, which consisted of a two-factor structure, were obtained. Cronbach's alpha was 0.84 in the total SSHP, and in subscales, alpha in the self-determination factor concerning self-care and patient-medical staff relationship were 0.83 and 0.78 , respectively, indicating that the reliability was maintained. Conclusion: We created SSHP which consisted of a two-factor structure and 14 questionnaires, and confirmed its validity and reliability.

\section{緒言}

患者の自己決定は，インフォームド・コンセントと 共に問題にされ始めた医療における新しい課題であ る。わが国では 1992 年の医療法の第 2 次改正により, 医療倫理の中でインフォームド・コンセントが取りあ げられたことで，自己決定について考えることがさら に重要になってきている1).

米国でも医療に関する患者の決定権の知識と行使の 普及を目指す, 患者の自己決定法 (Patient SelfDetermination Act）の制定や，医療に対しての意思表 明ができなくなったときの延命治療の実施・不実施の 希望を表明する事前指示書 (Advance Directive) の 普及を推進しはじめている ${ }^{2,3)}$ 。つまり, 患者の自己決 定について考え尊重することは, 法的側面, 倫理的側 面からも国際的にも意義深いことといえる。

しかし，患者なりの自己決定が，医療者が推奨する ものと合わないこともあり，患者のことを時に「病識 のない患者」とか「わがままな患者」とみてしまうた めに，両者にとってストレスとなることもある．特に 透析患者は療養期間が長期にわたるため, 自分の生活 にあった方法や，自分なりの目安で食事内容や水分摂 取量を自己決定している人が多く, 透析患者の自己決 定は医療者にとってのストレッサーとなっている。

Muthny ${ }^{4)}$ は，透析看護婦が仕事上緊張したりストレ スを感じる要因の一つに，患者が自己決定して医療者 へ要求することがあると述べている。わが国の透析看 護婦 4458 人を対象に行った調査でも，仕事上のスト レッサーは人間関係が最も多く，その対象として看護 婦同士の人間関係の次に，患者との関係をあげてい る5 . これらのことから, 透析患者の自己決定について 研究することは, 法的側面, 倫理的側面に加えて, 患 者一医療者関係を円滑にするために必要であるといえ よう。

そのため，筆者らはまず透析患者の自己決定につい て理解するために, 内容分析により自己決定の理由と 自己決定行動について明らかにした ${ }^{6)}$. 次に, 自己決定 の度合や状態を測定することも自己決定に関する問題 解決の一助となるため, 自己決定を測定する尺度の開
発が必要と考えた，そこで今回，透析患者の自己決定 尺度 (The Self-Determination Scale for Hemodialysis Patients, 以下 SSHP) の開発を行い, その信頼性 と妥当性 ${ }^{711)}$ を検証した。

\section{I . SSHP の概念と先行研究}

今回開発した SSHP で測定する自己決定とは, どの ような概念に基づくものとして作成したかについて述 ベる。

新井 ${ }^{12)}$ は近年の自己決定に関する研究をまとめ, 自 己決定とは活動を行うことを自分の意志で決定したと いう認知や感情であると述べている。いやいやながら 物事を決めても，喜んで物事を決めても自分で決めた ことである。しかし，自己決定とは，自分が好んで決 定したことを意味するという。

そこでSSHP は, 新井の自己決定の定義に従い, 透 析療法やセルフケアに関する状況において, 活動を行 うことを自分の意志で決定したという認知と感情を問 う尺度とした。同時に, 自己決定の目的としてはSSHP では，患者が満足する生活を送ることを目的とした自 己決定について測定するものとした。なおここでの セルフケアとは，専門家の意見を参考にしながらも最 終的な判断は自分で行うケアのことを意味する。

次に, 自己決定を測定する尺度開発に関する先行研 究について概観する。

保健医療分野で自己決定に関する尺度開発の試みは 少なく, 目立ったところでは $\operatorname{Cox}^{13)}$ の保健に関する自 己決定指標 (The Health Self-Determinism Index, 以下 HSDI) しかない. HSDI の構造は, 内発的動機と 有能感は関連しているという理論に導かれている。

HSDI は, 作成当初 20 項目の質問紙であったが, 因 子分析の結果, 16 項目 4 つの下位尺度からなる質問紙 となっている。信頼性を表す Cronbach's $\alpha^{7 \sim 11)}$ はすべ ての項目で .84, 下位尺度は .67 以上であり十分とは いえない.さらに3つの質問項目が 2 因子以上に寄与 していたり, 因子負荷量も.30以下のものもあるなど 構成概念妥当性 ${ }^{711}$ に問題がある.

次に地域住民に対して HSDI を用いた調査を行い, HSDI が test-retest 法にて安定性 ${ }^{7211)}$ があることを 
表 1 Demographic characteristics of the subjects （）\%

\begin{tabular}{lcc}
\hline & Second step $(\mathrm{n}=73)$ & Third step $(\mathrm{n}=201)$ \\
\hline Average of age & $52.4 \pm 13.7$ & $56.1 \pm 12.1$ \\
Gender & & \\
$\quad$ Male & $46(63.0)$ & $118(58.7)$ \\
$\quad$ Female & $27(37.0)$ & $83(41.3)$ \\
Employment Status & & \\
$\quad$ Employed & $38(52.1)$ & $87(43.3)$ \\
$\quad$ Unemployed & $31(42.5)$ & $108(53.7)$ \\
$\quad$ No answer & $4(5.5)$ & $6(3.0)$ \\
Average duration of & & $122.6 \pm 146.2$ \\
$\quad$ hemodialysis(months) & $78.5 \pm 77.2$ & \\
\hline
\end{tabular}

検証している14). しかし, Cronbach's $\alpha$ が.60 以下に なる下位尺度もあり，信頼性が保てているとはいいが たい. Campbel1 ${ }^{15}$ は，HSDI を自己決定測定の尺度と して使用し，体重管理において関連のある要因を明ら かにする研究を行っている。ここで使用したHSDI は，Cox が因子分析を行う前の 20 項目の質問で調査 を行っている, Cronbach's $\alpha$ は .87 であるが, 因子分 析に関する記載はなく，構成概念妥当性は検証されて いない. 結果は, HSDI は動機づけ尺度とされているに もかかわらず体重管理に関連しておらず, Campbell はHSDI の改良が必要であると考察している。しか し, Hawkers \& Holm ${ }^{16)}$ は, HSDI で測定した自己決 定が，身体活動の予測因子として関連していたと報告 しており結果は一定していない.

これらの報告より，HSDI は自己決定を測定する尺 度として参考にはなるものの，特に構成概念妥当性に 問題があり，新しい自己決定尺度の開発が必要である と考える。

\section{II. 対象および方法}

SSHP の開発は，次の三つのステップを通して行っ た。第一ステップはアイテム・プールとカテゴリー化 である。ここではまず，筆者が血液透析患者 25 名に半 構成的インタビューを行った結果 ${ }^{6}$ から，自己決定の カテゴリー化と質問項目の作成を行った。次に 7 人の 看護学研究者と 1 人の心理学研究者， 4 人の透析看護 に従事している看護婦による，質問項目の表面妥当性 と内容妥当性 ${ }^{711)}$ の検討を行った。検討には各質問項 目に対し，研究者らが提示したカテゴリーが該当する かどうかを記載してもらった。

質問項目作成にあたり，自分で決めているかを測定 するのに「〜について決めていますか」という質問の みで尋ねるのは，自己決定について正確に測定できな い可能性があると考えた。 その理由は，日本人の文化
的特性として，医療者におまかせする「おまかせ医療」 の傾向にあり，実際の場面では自己決定を行っていて も，個人の認識の中では自分が主体となって自己決定 を行っているとは認識していないことが多いからであ る。

そこで, 自己決定の理由の有無を尋ねることにより， 活動を自分で積極的に決めているかどうかの認知を客 観的計測值に表すことができるのではないかと推察し た。自己決定を行うには何らかの理由があるわけで, 自己決定の理由を有していれば，自己決定を行うこと につながると考えられる。日本人には自己抑制型が多 い17)ことを考えると，質問紙で自己決定を測定するな らば自己決定の理由を質問項目にいれることは妥当と 考えた。そこで，本尺度では自分の意志で決定するた めの理由を有しているかの認知を問う代用質問を含め た.

第二ステップはアイテム・セレクトで，第一ステッ プで作成した質問項目について，外来通院血液透析患 者を対象に調査を行った。調査用紙配布数は 78 名, 有 効回答 73 名であった. 対象者の属性は表 1 に示すとお りである.また, 基準関連妥当性 ${ }^{7 \sim 11}$ 検討のため, HSDI も同時に測定した。 HSDI は前述のような構成概念妥 当性に関する問題はあるものの, 自己決定に関する唯 一の尺度であるため参考尺度として使用した。

第三ステップはアイテム決定であり，第二ステップ で作成した項目を外来通院血液透析患者に調査を行っ た。調查用紙は 230 名に配布し, 有効回答 201 名であっ た。対象者の属性は表 1 に示すとおりである。

調査用紙は研究者が配布し即日回収を行った。即日 回収不可能な者には，封筒を添え厳封の上看護婦に渡 すよう伝えた。 
表 2 The question items of the first step

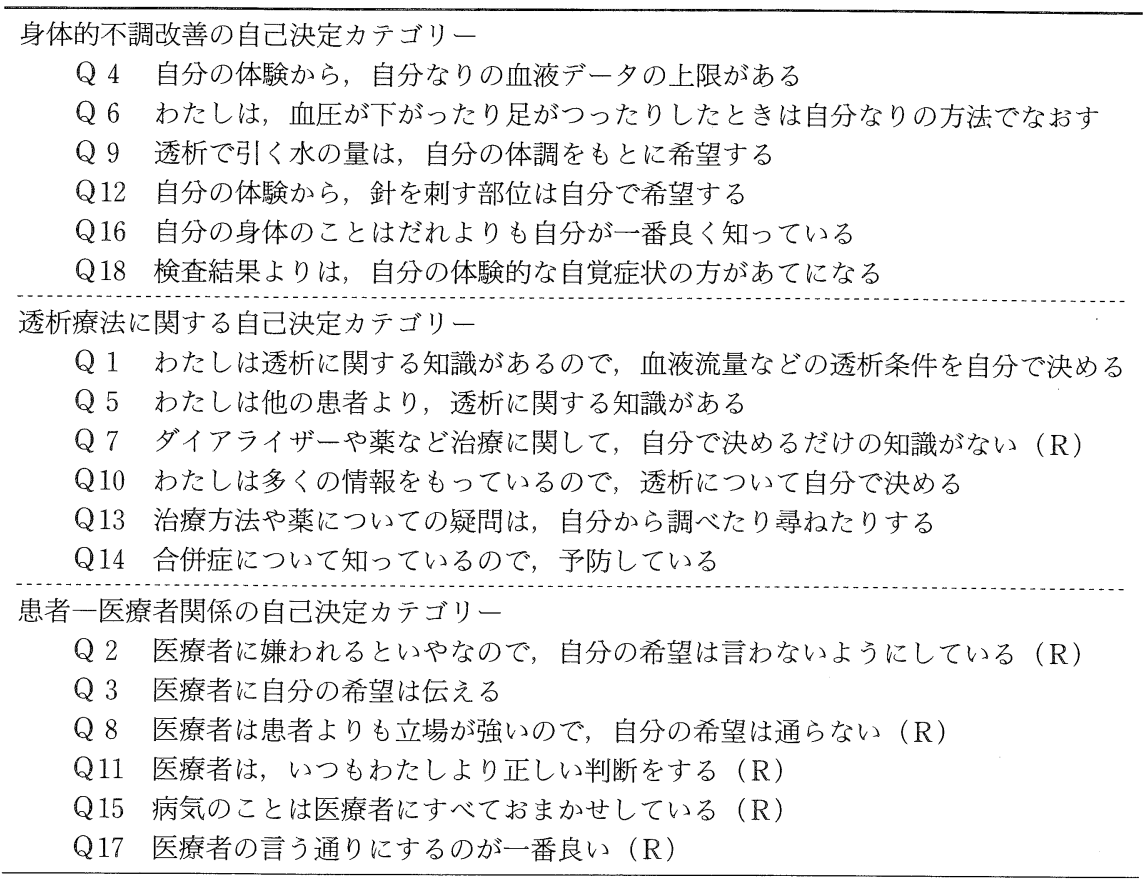

*（R）は逆転項目

\section{III、結果および考察}

\section{1. 第一ステップ \\ ーアイテム・プールとカテゴリー化一}

SSHP の質問作成には，患者へのインタビュー内容 を参考にした結果，4つの自己決定カテゴリーからな るものとした。その 4 カテゴリーとは，「自分の人生は 自分で決めている」などの質問項目からなる，生きる ことへの積極的態度に関する自己決定, 「自分の体験か ら，針を刺す部位は自分で希望する」などの質問項目 からなる身体不調改善の自己決定,「ダイアライザーや 薬など治療に関して, 自分で決めるだけの知識がある」 などの透析療法に関する自己決定,「医療者の言うとお りにするのが一番良いとは限らない」などの質問項目 からなる, 患者一医療者関係における自己決定である. これら 4 カテゴリーに対応する質問項目は，筆者らの インタビューによる患者からの発言を参考にして 31 項目作成した。

次に, 研究者と臨床看護婦による, 31 の質問項目の 表面妥当性と内容妥当性の検討を行った。その結果, 生きることへの積極態度に関する自己決定カテゴリー は, 透析療法やセルフケア状況にかかわらず，常に自 己決定的な性格特性に関するカテゴリーであり普遍的 な場合が多いとの意見があがった。 SSHP は透析療法 やセルフケア状況に打ける自己決定を測定することが
目的であるため，生きることへの積極的態度に関する 自己決定カテゴリーを削除した。また，質問項目とカ テゴリーの研究者間の一致率が，50\%未満である項目 も削除した。その結果，3 カテゴリー18 項目からなる 質問票を作成した（表 2 ）。選択肢は，1）そうではな い，2）あまりそうではない，3）どちらともいえな い，4）まあそうである，5）そうであるの 5 択とし， 自己決定度が高いほど高得点となるようにした。

\section{2. 第ニステップーアイテム・セレクトー}

第二ステップでは，73 名の透析患者に 18 の質問項 目に回答してもらった結果の分析を行った。まず質問 票の item-total 相関 (以下 I-T 相関) を検討した。 Q 8 「医療者は患者よりも立場が強いので，自分の希望 は通らない (逆転項目)」のみは, $\mathrm{r}=-.047 て ゙ \mathrm{I}-\mathrm{T}$ 相 関がみられなかった。そのため，「医療者は患者よりも 立場が強い」という前提条件が，自己決定の理由とし て適合しなかったのではないかと考え，Q8の項目を 削除した。

Q 8 を削除した 17 質問で, 主因子法バリマックス回 転にて因子分析を行い，構成概念妥当性を検討した。 その結果，表 3 に示すような 2 因子が見出された。

第 I 因子は身体不調改善カテゴリーと透析療法カテ ゴリーを統合したものとなったため，第 I 因子はセル フケアに関する自己決定因子とした。その理由は，以 下の通りである。身体不調改善の質問項目は透析中の 下肢筋けいれん痛や針の第刺痛の回避など，自分の体 
表 3 Factor analysis of the 17 question items

\begin{tabular}{|c|c|c|c|c|}
\hline & \multirow{2}{*}{\multicolumn{2}{|c|}{ Question items }} & \multicolumn{2}{|c|}{ Factor loading } \\
\hline & & & Factor I & Factor II \\
\hline \multirow[b]{3}{*}{$セ$} & Q 4 & 自分の体験から, 自分なりの血液デー夕の上限がある & 686 & 250 \\
\hline & Q12 & 自分の体験から，針を刺す部位は自分で希望する & 645 & 023 \\
\hline & Q13 & $\begin{array}{l}\text { 治療方法や薬についての疑問は, 自分から調べたり尋 } \\
\text { ね2たりする }\end{array}$ & 602 & 151 \\
\hline$>$ & Q 5 & わたしは他の患者より，透析に関する知識がある & 602 & 222 \\
\hline ケ & Q 9 & 透析で引く水の量は, 自分の体調をもとに希望する & 582 & 024 \\
\hline $\begin{array}{l}ア \\
k\end{array}$ & Q10 & $\begin{array}{l}\text { わたしは多くの情報をもっているので, 透析について } \\
\text { 自分で決める }\end{array}$ & 549 & 185 \\
\hline 関 & Q14 & 合併症について知っているので，予防している & 538 & 126 \\
\hline $\begin{array}{l}\text { す } \\
\text { る }\end{array}$ & Q 1 & $\begin{array}{l}\text { わたしは透析に関する知識があるので, 血液流量など } \\
\text { の透析条件を自分で決める }\end{array}$ & 507 & 057 \\
\hline $\begin{array}{l}\text { 自 } \\
\text { 己 }\end{array}$ & Q 7 & $\begin{array}{l}\text { ダイアライザーや薬など治療に関して, 自分で決める } \\
\text { だけの知識がない }(\mathrm{R})\end{array}$ & 501 & 035 \\
\hline \multirow[t]{3}{*}{$\begin{array}{l}\text { 決 } \\
\text { 定 }\end{array}$} & Q 6 & $\begin{array}{l}\text { わたしは, 血圧が下がったり足がつったりしたときは } \\
\text { 自分なりの方法でなおす }\end{array}$ & 499 & 208 \\
\hline & Q16 & $\begin{array}{l}\text { 自分の身体のことはだれよりも自分が一番良く知って } \\
\text { いる }\end{array}$ & 497 & 138 \\
\hline & Q 3 & 医療者に自分の希望は伝える & 280 & 195 \\
\hline \multirow{5}{*}{ 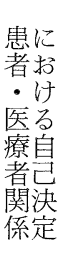 } & Q11 & 医療者は, いつもわたしより正しい判断をする（R) & 083 & 857 \\
\hline & Q17 & 医療者の言う通りにするのが一番良い（R） & -.024 & 780 \\
\hline & Q15 & 病気のことは医療者にすべておまかせしている（R） & 301 & 703 \\
\hline & Q18 & $\begin{array}{l}\text { 検査結果よりは，自分の体験的な自覚症状の方があて } \\
\text { になる }\end{array}$ & 083 & 384 \\
\hline & Q 2 & $\begin{array}{l}\text { 医療者に嫌われるといやなので，自分の希望は言わな } \\
\text { いうにしてる（R) }\end{array}$ & 092 & 128 \\
\hline
\end{tabular}

*（R）は逆転項目

調改善のためのセルフケアに関する自己決定のことで ある。また，透析療法に関する自己決定の質問項目も， 自分にあった薬剤の選択や合併症予防という自分の健 康保持のためのセルフケアに関する自己決定といえる からである、第II因子は第一ステップで分類したカテ ゴリーとほほ等しく，患者一医療者関係氾抢ける自己 決定因子とした。

Q 3 「医療者に自分の希望は伝える」は，因子負荷 量が，280 と低かったが, 第二ステップは予備調査で あるため削除しないことにした。しかしＱ２「医療者 に嫌われるといやなので，自分の希望は言わないよう にしている (逆転項目)」は, 因子負荷量が .200 以下 と低く，構成概念を乱すものとして削除した，Q 20 因子負荷量が低值だった理由として，この質問がQ 8 と同様に「医療者傔わ机るといやなので」という前 提条件が，自己決定の理由として適合しなかったので はないかと考元られる。自己決定は，無秩序や非合法 則性を指す自由意志を意味するものではない ${ }^{18)}$.「嫌わ れるといや」というのは感情であり，そのような否定 的感情からは，虚言などの無秩序な行動をとることも 考えられ，これはSSHP で測定しょうとしている自己 決定とは合致しない。そそのため，Q 2 は自己決定の構
成概念に包含されなかったのではないかと思われる。 尺度の信頼性を検討するために，内部一貫性を表す Cronbach's $\alpha$ を求めた。 その結果, 18 の質問項目から Q 8 とQ 2 を削除した 16 の質問全体で $\alpha=.86$, 下 位尺度ではセルフケアに関する自己決定の因子が $\alpha=.85$, 患者一医療者関係に㧍ける自己決定の因子 が $\alpha=.77$ であり，信頼性が保たれていることが確認 された。

基準関連妥当性検討のための HSDI との相関係数 を求めたところ, $\mathrm{r}=.67(\mathrm{p}<.001)$ と相関が高く,

SSHP の基準関連妥当性が認められた。

ここで再度, 質問項目の内容妥当性を検討したとこ ろ，Q1「わたしは透析に関する知識があるので，血 液流量などの透析条件を自分で決める」とQ７「ダイ アライザーや薬など治療に関して, 自分で決めるだけ の知識がない(逆転項目)」は，同様の意味と思われた． さらに，法律上，透析条件を患者が決めることはでき ないため，Q1を削除した。また，Q７は「知識がな い」という否定型の質問になっており，回答時に混乱 することが考えられたため,「ダイアライザーや薬など 治療に関して, 自分で決めるだけの知識がある」とい う肯定質問に变更した。 
表 4 Factor analysis of the 14 question items

\begin{tabular}{|c|c|c|c|c|}
\hline & \multirow{2}{*}{\multicolumn{2}{|c|}{ Question items }} & \multicolumn{2}{|c|}{ Factor loading } \\
\hline & & & Factor I & Factor II \\
\hline & Q 7 & $\begin{array}{l}\text { わたしは多くの情報をもっているので，透析について } \\
\text { 自分で決める }\end{array}$ & 602 & .187 \\
\hline $\begin{array}{l}セ \\
ル\end{array}$ & Q10 & $\begin{array}{l}\text { 治療方法や薬についての疑問は, 自分から調べたり尋 } \\
\text { ねたりする }\end{array}$ & .588 & .158 \\
\hline $\begin{array}{l}7 \\
r\end{array}$ & Q11 & 合併症について知っているので，予防している & 579 & .103 \\
\hline > & Q 5 & $\begin{array}{l}\text { ダイアライザーや薬など治療に関して, 自分で決める } \\
\text { だけの知識がある }\end{array}$ & 573 & 236 \\
\hline $\begin{array}{l}\text { に } \\
\text { 関 } \\
\text { す }\end{array}$ & Q 4 & $\begin{array}{l}\text { わたしは，血圧が下がったり足がつったりしたときは } \\
\text { 自分なりの方法でなおす }\end{array}$ & 542 & 014 \\
\hline る & Q13 & $\begin{array}{l}\text { 自分の身体のことはだれよりも自分が一番良く知って } \\
\text { いる }\end{array}$ & 540 & 023 \\
\hline 目 & Q 3 & わたしは他の患者より，透析に関する知識がある & .518 & .080 \\
\hline 決 & Q15 & $\begin{array}{l}\text { 検査結果よりは, 自分の体験的な自覚症状の方があて } \\
\text { になる }\end{array}$ & 490 & .287 \\
\hline 足 & Q 9 & 自分の体験から，針を刺す部位は自分で希望する & .487 & 109 \\
\hline & Q 6 & 透析で引く水の量は，自分の体調をもとに希望する & 483 & .226 \\
\hline & Q 2 & 自分の体験から, 自分なりの血液データの上限がある & .479 & .134 \\
\hline 患に & & & & \\
\hline 疾亏 & Q14 & 医療者の言う通りにするのが一番良い（R） & .165 & 795 \\
\hline 療息 & Q 8 & 医療者は，いつもわたしょり正しい判断をする（R） & .099 & 693 \\
\hline 简户 & Q12 & 病気のことは医療者にすべておまかせしている（R） & .161 & 690 \\
\hline
\end{tabular}

以上の分析により，第二ステップでは構成概念妥当 性, 基準関連妥当性, 内容妥当性, 信頼性を検討しア イテム・セレクトを行い, 2 因子構造 15 項目からなる 質問票を作成した。

\section{3. 第三ステップーアイテム決定一}

第三ステップでは, 201 名の透析患者に 15 の質問項 目を回答してもらった結果の分析を行った，分析は第 二ステップと同様, I-T 相関検討の後, 因子分析を行っ た。

I-T 相関では Q 1 「医療者に自分の希望は伝える」と 全項目との相関係数が， $r=.280$ と低く,第二ステッ プでも因子負荷量が低值を示していたことから質問項 目から削除した。自己決定には人生を左右するような 重大なものから，日常的に行われているさほど重要で ない自己決定など，さまざまな水準がある ${ }^{18)}$ ，一概に， 医療者に自分の希望は伝えるかどうかを問われても， 「血圧測定してほしい」といった日常的に行われている 希望伝達から, 延命治療の決定など重要度の高い希望 伝達まで, 自己決定の水準には各個人で大きな相違が ある。そのため，「医療者に自分の希望は伝える」とい う質問が他の項目に比し，同等水準での自己決定が測 定できていなかったことが推考される，Q1以外の質 問項目は， $\mathrm{r}=.422 \sim .654$ の有意相関を示してい た.
次に，構成概念妥当性の検討のため，Q１を除いた 14 項目で因子分析を行った(表 4)。その結果, 第二ス テップと同様のセルフケアに関する自己決定の因子 と, 患者一医療者関係に括ける自己決定の 2 因子構造 となった。この 2 因子に扔いて, 因子負荷量が .400以 下のものはなく，構成概念妥当性は確認された。

信頼性の検証のため，14 項目となった質問票の Cronbach's $\alpha$ を求めた。1 14 項目全体の $\alpha$ 係数は $\alpha=.84$, 下位尺度であるセルフケアに関する自己決 定因子では $\alpha=.83$, 患者一医療者関係における自己 決定因子では $\alpha=.78$ であり, 信頼性が保たれている ことが確認された。

第三ステップでは, 構成概念妥当性の再検討と信頼 性の検討を行い，血液透析患者の自己決定を測定する SSHP は，表 4 に示す 14 の質問項目が適当と判断し た.

\section{結 論}

血液透析患者が，透析療法やセルフケアに関する活 動を行うことを自分の意志で決定したという認知と感 情を問う尺度, SSHP の開発を試みた。質問項目の表 面妥当性, 内容妥当性, 構成概念妥当性, 基準関連妥 当性, 信頼性を検証し, セルフケアに関する自己決定 
因子と患者一医療者関係に拈ける自己決定の 2 因子構 造からなる 14 項目の尺度を作成した。

本稿をまとめるにあたり，ご指導いただきました筑波大 学・宗像恒次助教授に深謝いたします。また, 横浜第一病 院・日台英雄院長をはじめ, 本研究にご協力ご助言いただ きましたみなさまに心より謝意を表します。

本研究は, 第 2 回社団法人日本透析医学会コメディカル スタッフ研究助成, 財団法人笹川医学医療研究財団看護職 員等に対する研究助成, 財団法人慢性疾患・リハビリテイ ション研究振興財団からの研究助成金の一部で行った。

\section{文献}

1）相磯富士雄：医療に招ける自己決定の条件. 日本保健 医療行動科学会年報 $11 ： 1-3,1996$

2）丸山英二：患者の自己決定法. 法学セミナー460：110 $-111,1993$

3) Glick HR, Cowart ME, Smith JD : Advance medical directives in U.S. hospitals and nursing homes. Politics and the Life Sciences 14 : 47-59, 1995

4) Muthny FA: Job strains and job satisfaction of dialysis nurses. Psychotherapy and Psychosomatics $51: 150-155,1989$

5）日本腎不全看護研究会：日本腎不全看護研究会アン ケート調査結果. 日本腎不全看護研究会報告書：71$72, \quad 1995$

6）岡美智代，安酸史子， 戸村成男，土屋 滋：血液透析 患者のセルフケアと透析療法における自己決定に関す る研究一自己決定理由と行動の内容分析一。 日本保健
医療行動科学会年報 $12 ： 171-187,1997$

7）福武 直：社会測定の技術. 社会調査 - 補訂版. p 176 -208 , 岩波書店, 東京, 1984

8）Carmines E, Zeller R（水野欽次訳）：テストの信頼性 と妥当性。朝倉書店, 東京, 1988

9）南裕子, 押尾祥子：デー夕の収集, 看護における研 究 (井上幸子, 平山朝子, 金子道子編), p 91-117, 日 本看護協会出版会, 東京, 1991

10）岡美智代：透析患者におけるセルフケアとその関連要 因（6） 尺度と慢性疾患患者の自己効力感の測定方法. 臨牀透析 $12: 1803-1806,1996$

11) Burns N, Grove SK : The concepts of measurement, The practice of nursing research, p 319-341, W. B. Saunders Company, Philadelphia, 1997

12）新井邦二郎：小学生の自己決定経験の調査。筑波大学 心理学研究 $18: 75-99,1996$

13) Cox CL: The Health Self-Determinism Index. Nursing Research 34:176-183, 1985

14) Cox CL, Wachs JE : Motivation: Vehicle for public health nursing interventions ?. Public Health Nursing $4: 202-212,1985$

15) Campbell BF : Self-determination, self-efficacy, and successful self-regulation of weight. University of South Carolina, Doctoral Dissertation, UMI Dissertation Services ; 1991

16) Hawks JH, Holm $\mathrm{K}:$ Gender differences in exercise determinants. Nursing Research $42: 166-172,1993$

17）宗像恒次：自己決定の行動科学. 日本保健医療行動科 学年報 $11: 1-14,1996$

18）Deci EL (石田梅男訳)：自己決定の心理学。誠信書房, 東京, 1985 